\title{
Peningkatan Kemandirian Anak Usia 4-5 Tahun Melalui Bercerita
}

\author{
Mariana Ikun RD Pareira \\ Naomi Habi Atal \\ Program Studi Pendidikan Luar Sekolah Fakultas Keguruan dan Ilmu Pendidikan \\ Universitas Nusa Cendana \\ Email: marianaikun.pareira@gmail.com
}

Received February 2019, Accepted March 2019, Published April 2019

\begin{abstract}
Autonomy is important to be taught early because makes it will easier for children to carry out further education. Autonomy also leads children to have high self-esteem and intrinsic motivation. The most prominent problem in children at TK Tunas Harapan Emaus Liliba Kupang is autonomy. Autonomy can be promoted in various ways, one of them which is story telling. The purpose of this study is to find out whether there is an increase in autonomy of children ages 4-5 years after story telling. The research method used in this research is experimental method with quantitative approach. The research design used is a non-equivalent research design or also called "one group pre test and post test design" which is a research design used by giving before and after the activitiies test in a single group research sample. The results of this study indicate that by the Wilcoxon test showed a significant increase in autonomy of children ages $4-5$ years $(p<0.05)$.
\end{abstract}

Keywords: Autonomy, Children Ages 4-5 Years, Story Telling

\begin{abstract}
Abstrak: Kemandirian perlu diajarakan sejak dini karena akan memudahkan anak dalam memasuki jenjang pendidikan selanjutnya. Kemandirian juga mengantarkan anak untuk memiliki kepercayaan diri dan motivasi instrinsik yang tinggi. Permasalahan yang paling menonjol pada anak-anak di TK Tunas Harapan Emaus Liliba Kupang adalah kurangnya kemandirian. Kemandirian dapat dilatih dengan berbagai cara, salah satunya melalui bercerita. Tujuan penelitian ini adalah ingin mengetahui apakah terdapat peningkatan kemandirian anak usia 4-5 tahun setelah bercerita di TK Tunas Harapan Emaus Liliba, Kota Kupang. Metode penelitian yang digunakan dalam penelitian ini adalah metode eksperimen dengan pendekatan kuantitatif. Desain eksperimen yang digunakan adalah desain penelitian non equivalent atau disebut juga "one group pre test and post test design" yaitu sebuah desain penelitian yang digunakan dengan cara memberikan tes sebelum dan sesudah kegiatan pada sampel penelitian kelompok tunggal. Hasil analisis data dengan uji Wilcoxon menunjukkan peningkatan yang signifikan pada kemandirian anak usia 4-5 tahun $(\mathrm{p}<0,05)$.
\end{abstract}

Kata kunci: Kemandirian, Anak Usia 4-5 Tahun, Cerita Bergambar

\section{PENDAHULUAN}

Undang-undang Sisdiknas No.20

Tahun 2003, Pasal 1 ayat 14 menyatakan bahwa pendidikan anak usia dini adalah upaya pembinaan yang ditujukan kepada anak sejak lahir sampai usia 6 tahun, yang dilakukan melalui pembelajaran. Pendidikan merupakan hal yang sangat mendasar bagi kehidupan manusia, salah satunya adalah Pendidikan Anak Usia Dini (PAUD). PAUD merupakan pendidikan pertama dan utama dalam kehidupan anak, sehingga masa ini diharapkan guru maupun orang tua dapat merangsang perkembangan anak.

Usia dini merupakan saat yang paling tepat untuk memberikan stimulasi dan rangsangan yang baik untuk perkembangan anak. Hal ini sejalan dengan yang dikemukakan oleh Suyanto (2005: 6) bahwa anak usia dini merupakan masa emas atau golden age, dimana potensi yang dimiliki anak berkembang dengan pesat baik itu perkembangan fisik motorik, sosial emosional, kognitif maupun bahasa. Seluruh aspek perkembangan tersebut harus diberikan stimulus agar dapat berkembang secara seimbang.

Berdasarkan pernyataan di atas, menunjukkan bahwa Pendidikan Anak Usia Dini merupakan salah satu jalur pendidikan yang dapat mengembangkan perkembangan anak secara menyeluruh. Mengingat pentingnya pendidikan ini maka diperlukan pendidik yang dapat memberikan stimulasi dan bimbingan untuk perkembangan anak. Pendidikan ini diharapkan dapat melahirkan generasi yang baik, baik secara fisik maupun psikisnya sesuai dengan tuntutan perkembangan usia anak tersebut. 
Usia Taman Kanak-kanak (TK) merupakan masa peka bagi anak, di mana anak mulai sensitif untuk menerima berbagai upaya perkembangan seluruh potensi anak. Masa peka adalah masa terjadinya pematangan fungsi-fungsi fisik dan psikis yang siap merespon stimulasi yang diberikan oleh lingkungan. Pada masa ini merupakan masa untukmeletakkan dasar pertama dalam mengembangkan kemampuan fisik, kognitif, bahasa, sosial emosional, konsep diri, disiplin, kemandirian, seni, moral dan nilai-nilai agama. Oleh sebab itu dibutuhkan suasana belajar, strategi dan stimulus yang sesuai dengan kebutuhan anak agar pertumbuhan dan perkembangan anak tercapai secara optimal (Yamin, 2010:3).

Departemen Pendidikan Nasional (2010) menjabarkan tingkat pencapaian perkembangan anak usia 4-5 tahun pada lingkup sosial emosional meliputi sikap mandiri dalam memilih kegiatan, menunjukkan rasa percaya diri, mau berbagi, menolong, dan membantu teman. Oleh karena itu, pihak sekolah dan orang tua harus bekerjasama mengembangkan aspek sosial emosional anak yang sangat penting untuk bekal anak hidup bermasyarakat.

Menurut Yamin

kemandirian termasuk pada aspek pengembangan sosial-emosional. Kompetensi dan hasil belajar yang ingin dicapai adalah kemampuan mengenal lingkungan alam, lingkungan sosial, peranan masyarakat dan menghargai keragaman sosial budaya serta mampu mengembangkan konsep diri, sikap positif terhadap belajar, kontrol diri, rasa memiliki, motivasi dan kreativitas. Sedangkan menurut Uno (2006: 77) mengartikan kemandirian sebagai kemampuan untuk mengarahkan dan mengendalikan diri dalam berpikir dan bertindak, serta tidak merasa bergantung pada orang lain secara emosional.

Dari pendapat para ahli di atas menunjukkan bahwa kemandirian merupakan suatu sikap dari anak yang menunjukkan sebuah usaha yang dilakukan secara mandiri tanpa harus disuruh dan tanpa bantuan orang lain.

Anak yang belum mandiri biasanya rentan terhadap kecemasan, ketakutan saat sendirian, selalu ditunggu ibu saat sekolah, ingin bersama orang lain, kecemasan melakukan sesuatu tanpa bantuan orang lain, serta kecemasan ketika diberi tugas atau pertanyaan yang belum dikuasai anak (Kennedy, 2004: 6). Dampak ketidakmandirian anak pada usia selanjutnya dalam konteks proses belajar, dewasa ini tampaknya berkembang suatu gejala yang cukup mengkhawatirkan para pendidik. Gejala yang ditunjukkan antara lain berkurangnya perhatian siswa untuk belajar, kelalaian dalam mengerjakan tugas-tugas pekerjaan rumah, menunda persiapan ulangan, serta pandangan asal lulus atau asal naik kelas.

Berdasarkan hasil wawancara dan observasi lapangan permasalahan yang paling menonjol pada anak yang berusia 4 (empat) sampai 5 (lima) tahun di TK Tunas Harapan adalah masalah kemandirian yang belum tampak. Hal ini terlihat pada saat kegiatan di kelas atau pun saat bermain terdapat beberapa anak yang selalu ingin dibantu oleh guru ataupun sesama teman mereka, kurangnya rasa tanggung jawab terhadap perlengkapan makan dan peralatan main mereka sendiri.

Berdasarkan fenomena tersebut, peneliti ingin mengetahui kemandirian anak setelah menggunakan metode bercerita kepada anak.

\section{Kemandirian}

Menurut Sumahamijaya (2003) Kemandirian adalah kemampuan untuk melakukan kegiatan atau tugas sehari-hari sesuai dengan tahapan perkembangan dan kapasitasnya. Kemandirian berasal dari kata mandiri yang berarti dalam keadaan dapat berdiri sendiri, tidak bergantung kepada orang lain, tapi menggunakan kekuatan sendiri. Kemandirian diartikan sebagai sesuatu hal atau keadaan dapat berdiri sendiri tanpa bergantung pada orang lain.

Kemandirian bagi anak sangat penting, karena dengan mempunyai sifat mandiri anak tidak akan mudah bergantung kepada orang lain. Dengan mengacu pada definisi di atas, peneliti menyimpulkan bahwa sedikitnya ada 3 (tiga) unsur yang menyertai makna kemandirian bagi anak usia dini, antara lain: (1) Mampu melakukan sesuatu tanpa bantuan, (2) Berani tampil di depan orang, dan (3) Bertanggung jawab menerima konsekuensi yang menyertai pilihannya. 
Menurut Susanto (2012) ciri-ciri kemandirian anak usia dini adalah sebagai berikut:

1. Memiliki kepercayaan kepada diri sendiri. Anak yang memiliki rasa percaya diri memiliki keberanian untuk melakukan sesuatu dan menentukan pilihan sesuai dengan kehendaknya sendiri dan bertanggung jawab terhadap konsekuensi yang dapat ditimbulkan kerena pilihannya.

2. Memiliki motivasi intrinsik yang tinggi. Motivasi intrinsik merupakan dorongan yang berasal dari dalam diri untuk melakukan suatu perilaku maupun perbuatan. Motivasi intrinsik ini pada umumnya lebih kuat dan abadi dibandingkan dengan motivasi ekstrinsik walaupun kedua jenis motivasi tersebut bisa juga berkurang dan bertambah.

3. Mampu dan berani menentukan pilihannya sendiri. Anak yang berkarakter mandiri memiliki kemampuan dan keberanian dalam menentukan pilihannya sendiri.

4. Kreatif dan inovatif. Kreatif dan inovatif pada anak usia dini merupakan salah satu ciri anak yang memiliki karakter mandiri, seperti dalam melakukan sesuatu atas kehendak sendiri tanpa disuruh oleh orang lain, tidak bergantung terhadap orang lain dalam melakukan sesuatu, menyukai dan selalu ingin mencoba hal-hal yang baru.

5. Bertanggung jawab menerima konsekuensi yang menyertai pilihannya. Pada saat anak usia dini mengambil keputusan atau pilihan, tentu ada konsekuensi yang melekat pada pilihannya. Anak yang mandiri akan bertanggung jawab atas keputusan yang diambilnya apa pun yang terjadi. Tentu saja bagi anak usia dini tanggung jawab tersebut dilakukan dalam taraf yang wajar.

6. Mampu menyesuaikan diri dengan lingkungannya. Lingkungan kelompok bermain $(\mathrm{KB})$ maupun TK merupakan lingkungan yang baru bagi anak usia dini. Sering sekali kita menemukan dengan mudah anak yang menangis ketika pertama kali masuk KB maupun TK. Bahkan, kebanyakan anak ditunggui oleh orangtuanya ketika sedang belajar di kelas. Bagi anak yang memiliki karakter mandiri, dia akan cepat menyesuaikan diri dengan lingkungan yang baru dan dapat belajar walaupun tidak ditunggui orang tuanya.

7. Tidak bergantung pada orang lain. Anak yang memiliki karakter mandiri selalu ingin mencoba sendiri dalam melakukan segala sesuatu, tidak bergantung kepada orang lain dan dia tahu kapan waktunya meminta bantuan orang lain.

Indikator kemandirian anak usia 4-5 tahun yaitu sebagai berikut: 1). Memasang kancing dan resleting sendiri; 2). Memasang dan membuka tali sepat sendiri; 3). Mampu makan sendiri; 4). Berani pergi dan pulang sekolah sendiri (bagi yang dekat dengan sekolah); 5). Mampu memilih benda untuk bermain; 6). Mampu mandi, BAK, B AB (toilet training) masih dengan bantuan; 7). Mampu mengerjakan tugas sendiri; 8). Bermain sesuai dengan jenis permainan yang dipilihnya; 9). Mengurus dirinya sendiri dengan bantuan, misalnya: berpakaian

\section{Bercerita}

Dalam pendidikan anak usia dini, cerita sangat diperlukan dan banyak membantu peserta didik dalam memahami materi. Hal ini disebabkan sebagian besar anak-anak menyukai cerita, kisah atau dongeng. Cerita adalah salah satu cara untuk menarik perhatian anak. Seorang anak akan cenderung lebih senang menyimak cerita dari pada mendengarkan ceramah dari bapak atau ibu gurunya. Oleh karenanya, sebagai seorang pendidik anak usia dini perlu kiranya sesekali menggunakan metode cerita dalam kegiatan pembelajaran.

Itadz (2008) dalam penelitiannya menjelaskan beberapa alasan mengapa cerita sangat penting bagi dunia anak-anak.

1. Bercerita merupakan alat pendidikan budi pekerti yang paling mudah dicerna anak, di samping teladan yang dilihat anak setiap hari.

2. Bercerita merupakan metode dan materi yang dapat diintegrasikan dengan dasar keterampilan lain, yaitu berbicara, 
membaca, menulis, dan menyimak, tidak terkecuali untuk anak Taman Kanak-Kanak.

3. Bercerita memberikan ruang lingkup yang bebas pada anak untuk mengembangkan kemampuan bersimpati dan berempati terhadap peristiwa yang menimpa orang lain. Hal tersebut mandasari anak untuk memiliki kepekaan sosial.

4. Bercerita memberi contoh pada anak bagaimana menyikapi suatu permasalahan dengan baik, bagaimana melakukan pembicaraan yang baik, sekaligus memberikan pelajaran pada anak bagaimana cara mengendalikan keinginan-keinginan yang dinilai negatif oleh masyarakat.

5. Bercerita memberikan barometer sosial pada anak, nilai-nilai apa saja yang diterima oleh masyarakat sekitar, seperti patuh pada perintah orang tua, mengalah pada adik, dan selalu bersikap jujur.

6. Bercerita memberikan pelajaran budaya dan budi pekerti yang memiliki retensi lebih kuat dari pada pelajaran budi pekerti yang diberikan melalui penuturan dan perintah langsung.

7. Bercerita memberikan ruang gerak pada anak, kapan sesuatu nilai yang berhasil ditangkap akan diaplikasikan.

8. Bercerita memberikan efek psikologis yang positif bagi anak dan guru sebagai pencerita, seperti kedekatan emosional sebagai pengganti figure lekat orang tua.

9. Bercerita memberikan rasa tahu anak akan peristiwa atau cerita, alur, dan yang demikian itu menumbuhkan kemampuan merangkai hubungn sebab akibat dari suatu peristiwa dan memberikan peluang bagi anak untuk belajar menelaah kejadian-kejadian di sekelilingnya.

10. Bercerita memberikan daya tarik bersekolah bagi anak karena di dalam bercerita ada efek rekreatif dan imajinatif yang dibutuhkan anak usia dini (TK).

11. Bercerita mendorong anak memberikan makna bagi proses belajar terutama mengenai empati sehingga anak dapat mengkongkretkan rabaan psikologis mereka bagaimana seharusnya memandang sesuatu masalah dari sudut pandang orang lain.

Bercerita dapat dilakukan tanpa alat peraga maupun dengan menggunakan alat peraga. Bercerita dengan alat peraga adalah bentuk bercerita yang mempergunakan alat peraga bantu untuk menghidupkan cerita. Fungsi alat peraga ini untuk menghidupkan fantasi dan imajinasi anak sehingga terarah sesuai dengan yang diharapkan pencerita.

Siswa akan belajar lebih banyak dari pada jika materi itu hanya disajikan dengan stimulus pandang atau dengan stimulus dengar saja. Perbandingan pemerolehan hasil belajar melalui indera pandang dan indera dengar sangat menonjol perbedaannya. Hal ini sejalan dengan pernyataan Dale (dalam Arsyad, 2002) yang menyatakan bahwa pemerolehan hasil belajar seseorang melalui indra pandang berkisar $75 \%$, melalui indera dengar sekitar $13 \%$, dan indera lainnya sekitar $12 \%$.

\section{METODE}

Penelitian ini menggunakan jenis penelitian kuantitatif dengan pendekatan kuasi eksperimen. Menurut Sugiyono (2008) penelitian kuantitatif merupakan suatu proses menemukan pengertian menggunakan data berupa angka sebagai alat untuk menemukan keterangan mengenai apa yang diketahui.

Desain eksperimen yang akan digunakan adalah desain penelitian non equivalent atau disebut juga "one group pre test and post test design" yaitu sebuah desain penelitian yang digunakan dengan cara memberikan tes sebelum dan sesudah kepada sampel penelitian kelompok tunggal. Di dalam desain ini, observasi dilakukan sebanyak 2 (dau) kali, yakni sebelum eksperimen dan sesudah eksperimen. Observasi yang dilakukan sebelum eksperimen (O1) disebut pratest atau pretest dan observasi sesudah eksperimen (O2) disebut pascates atau posttest.

Perbedaan antara $\mathrm{O} 1$ dan $\mathrm{O} 2$ yakni $(\mathrm{O} 1$ O2) diasumsikan sebagai efek dari treatment atau perlakuan. Desain penelitian one group pre test and post test design dapat digambarkan seperti pada gambar 1 berikut (Arikunto, 2006): 


\section{$\mathrm{O} 1 \mathrm{X} \mathrm{O} 2$}

\section{Gambar 1. Desain Penelitian}

Keterangan:

O1: tes awal sebelum anak diberikan perlakuan (nilai pretest)

$\mathrm{X}$ : perlakuan di kelas berupa metode bercerita

O2: tes akhir sesudah anak diberikan perlakuan (nilai posttest)

\section{HASIL DAN PEMBAHASAN}

Penelitian ini dilakukan di TK Tunas Harapan Liliba Emaus Kupang dan subyek yang diteliti adalah anak usia 4-5 tahun di kelompok A sebanyak 11 (sebelas) anak. Langkah pertama dalam pengambilan data adalah melakukan test awal (pretest). Tes ini dilakukan untuk mengetahui skor siswa sebelum diberikan perlakuan (treatment).

Data skor awal (pretest) sebelum menerapkan pembelajaran dengan cerita bergambar pada anak usia 4-5 tahun di TK Tunas Harapan Emaus, Liliba sebelum diberikuan perlakuan dapat dilihat pada tabel 1 .

\section{Tabel 1. Daftar Skor Pretest}

\begin{tabular}{lllll}
\hline No & $\begin{array}{l}\text { Subjek } \\
\text { Penelitian }\end{array}$ & $\begin{array}{l}\text { Skor } \\
\text { pretest }\end{array}$ & Nilai & Predikat \\
\hline $\mathbf{1}$ & JM & 19 & 63 & Baik \\
\hline $\mathbf{2}$ & AD & 14 & 46 & Cukup \\
\hline $\mathbf{3}$ & AN & 21 & 70 & Baik \\
\hline $\mathbf{4}$ & GR & 16 & 53 & Cukup \\
\hline $\mathbf{5}$ & AX & 15 & 50 & Cukup \\
\hline $\mathbf{6}$ & IT & 23 & 76 & Baik \\
\hline $\mathbf{7}$ & LN & 16 & 53 & Cukup \\
\hline $\mathbf{8}$ & AL & 14 & 46 & Cukup \\
\hline $\mathbf{9}$ & GS & 14 & 46 & Cukup \\
\hline $\mathbf{1 0}$ & DN & 16 & 53 & Cukup \\
\hline $\mathbf{1 1}$ & WL & 16 & 53 & Cukup \\
\hline
\end{tabular}

Setelah melakukan pretes, langkah selanjutnya yaitu memberikan perlakuan, dalam hal ini bentuk perlakuannya adalah bercerita dengan menggunakan alat peraga yaitu gambar sesuai dengan rencana pelaksanaan pembelajaran.

Pelaksanaan kegiatan bercerita dilakukan sebanyak 3 (tiga) kali pertemuan (proses pembelajaran). Setelah diberikan perlakuan dengan bercerita dengan media bergambar, dilakukan test akhir (posttest). Skor yang diperoleh anak usia 4-5 tahun di TK Tunas Harapan Emaus, Liliba hasil posttest dapat dilihat pada tabel 2.

Penerapan metode bercerita dengan menggunakan media gambar efektif dalam meningkatkan kemandirian anak usia 4-5 tahun di TK Tunas Harapan Emaus Liliba, hal ini ditunjukkan melalui perbandingan hasil pretest (tes awal) dan posttest (tes akhir) yang tampak pada tabel 1 dan tabel 2 dimana pada saat pretest, diketahui bahwa 8 anak memperoleh skor pada kisaran 12-17 yakni setara dengan nilai 40-59 dengan predikat cukup, dan 3 anak memperoleh skor pada kisaran 18-23, yakni setara dengan nilai 60-79 dengan predikat baik.

Tabel 2. Daftar Skor Posttest

\begin{tabular}{|c|c|c|c|c|}
\hline No & $\begin{array}{l}\text { Subjek } \\
\text { Penelitian }\end{array}$ & $\begin{array}{l}\text { Skor } \\
\text { pretest }\end{array}$ & Nilai & Predikat \\
\hline 1 & JM & 27 & 90 & Sangat baik \\
\hline 2 & $\mathrm{AD}$ & 20 & 67 & Baik \\
\hline 3 & $\mathrm{AN}$ & 29 & 96 & Sangat baik \\
\hline 4 & GR & 21 & 70 & Baik \\
\hline 5 & $\mathrm{AX}$ & 21 & 70 & Baik \\
\hline 6 & IT & 27 & 90 & Sangat baik \\
\hline 7 & $\mathrm{LN}$ & 23 & 76 & Baik \\
\hline 8 & $\mathrm{AL}$ & 22 & 73 & Baik \\
\hline 9 & GS & 21 & 70 & Baik \\
\hline 10 & $\mathrm{DN}$ & 23 & 76 & Baik \\
\hline 11 & WL & 23 & 76 & Baik \\
\hline
\end{tabular}


Namun setelah diberikan perlakuan, maka terjadi peningkatan skor posttest pada anak kelompok A TK Tunas Harapan Emaus Liliba, dimana terdapat 8 anak yang memperoleh skor pada kisaran 18-23 yakni setara dengan nilai 60-79 dengan predikat baik, dan 3 anak yang memperoleh nilai pada kisaran 24-30 yakni setara dengan nilai 80-100 dengan predikat sangat baik.

Efektifitas metode bercerita dengan menggunakan media gambar juga ditunjukkan dari nilai hasil pengolahan data yang menggunakan uji statistik Wilcoxon, yakni nilai Thitung atau Asymp.Sig.(2-tailed) bernilai 0,003 . Karena nilai 0,003 lebih kecil dari nilai Ttabel yakni 0,05, maka dapat disimpulkan bahwa "Ha diterima". Artinya, ada perbedaan peningkatan kemandirian skor posttest dari skor pretest, sehingga dapat disimpulkan pula bahwa "terdapat peningkatan kemandirian anak dalam penerapan metode bercerita menggunakan media gambar terhadap anak usia 4-5 tahun di TK Tunas Harapan Emaus Liliba".

Hasil dari penelitian ini sejalan dengan apa yang dijelaskan oleh Moeslichatoen (2004), bahwa metode bercerita merupakan salah satu pemberian pengalaman belajar bagi anak dengan membawakan cerita kepada anak secara lisan. Dalam pelaksanaan kegiatan pembelajaran di PAUD metode bercerita dilaksanakan dalam upaya memperkenalkan, memberi keterangan, atau penjelasan tentang hal baru dalam rangka menyampaikan pembelajaran yang dapat mengembangkan berbagai aspek pada anak. Kegiatan bercerita dapat mengembangan aspek sikap mandiri anak yaitu, memiliki sikap percaya diri, disiplin, dan sikap bertanggung jawab yang ditunjukkan oleh tokoh-tokoh dalam cerita melalui media gambar. Dengan demikian gambar menjadi media pembelajaran yang utama dalam peningkatan sikap kemandirian anak.

Kegiatan pembelajaran dengan metode becerita menggunakan media gambar memberikan pengalaman belajar yang unik dan menarik perasaan, membangkitkan semangat dan menimbulkan kesenangan tersendiri bagi anak usia 4-5 ahun di TK Tunas Harapan Emaus Liliba. Hal ini sesuai dengan pernyataan yang diungkapkan oleh Miarso (2007: 458) yang mendefinisikan media pembelajaran, adalah segala sesuatu yang digunakan untuk menyalurkan pesan serta dapat merangsang pikiran, perasaan, perhatian, dan kemauan pelajar sehingga dapat mendorong terjadinya proses belajar yang disengaja, bertujuan, dan terkendali. Cerita yang dibawakan pun harus menarik dan mengundang perhatian tetapi tidak terlepas dari tujuan pembelajaran anak usia dini.

Belajar dengan menggunakan indera ganda, yaitu indera pandang dan indera dengar akan memberikan keuntungan bagi anak. Dalam penelitian ini ialah penerapan metode bercerita dengan menggunakan media gambar. Pengajaran yang melibatkan lebih dari satu indera disebut dengan pengajaran multisensori. Berkaitan dengan hal itu the International Dyslexia Association (IDA) menyatakan bahwa pengajaran multisensori adalah penggunaan indera visual, auditori, dan kinestetik-taktil secara serempak yang bertujuan untuk meningkatkan daya ingat dan pembelajaran siswa.

Siswa akan belajar lebih banyak dari pada jika materi itu hanya disajikan dengan stimulus pandang atau dengan stimulus dengar saja. Perbandingan pemerolehan hasil belajar melalui indera pandang dan indera dengar sangat menonjol perbedaannya. Hal ini berkenaan dengan apa yang telah disampaikan oleh Dale (dalam Arsyad, 2002) yang menyatakan bahwa pemerolehan hasil belajar seseorang melalui indra pandang berkisar $75 \%$, melalui indera dengar sekitar $13 \%$, dan indera lainnya sekitar $12 \%$.

Hal ini semakin diperkuat dengan pendapat Levie (dalam Arsyad, 2002:9) tentang belajar melalui stimulus gambar dan stimulus kata atau visual dan verbal yang menyatakan bahwa belajar melalui stimulus visual membuahkan hasil belajar yang lebih baik untuk tugas-tugas seperti mengingat, mengenali, mengingat kembali, dan menghubungkan fakta dan konsep.

Peningkatan perolehan skor yang di peroleh anak usia 4-5 tahun di TK Tunas Harapan Emaus Liliba dalam penerapan metode bercerita menggunakan media gambar 
memberikan satu kesimpulan bahwa media pembelajaran memperjelas penyajian pesan pembelajaran sehingga lebih jelas maknanya dan dapat lebih dipahami oleh anak dan memungkinkan anak menguasai tujuan pengajaran yang lebih jelas.

Terlepas dari pembahasan mengenai hasil penelitian tersebut di atas, terdapat beberapa faktor yang mendukung keberhasilan dari penelitian ini, yakni: pertama, pemilihan metode cerita yang tepat (aktivitas Rini di Rumah, Rini anak yang pandai di kelasnya, cerita Rini saat bermain), cerita yang disajikan dalam penelitian ini sesuai dengan kehidupan keseharian anak, baik saat berada di rumah maupun di sekolah. Kedua, penggunaan media pembelajaran yang menarik sebagai penunjang untuk membantu memudahkan anak memahami makna pembelajaran yang di sampaikan. Media yang digunakan dalam penelitian ini adalah berupa gambar dari tokoh dalam cerita yang beserta aktivitas yang dilakukannya. Ketiga, terjalin hubungan dan kerja sama yang baik dari guru-guru di TK Tunas Harapan Emaus Liliba, hal ini terlihat dimana penulis diperbolehkan untuk melakukan penelitian di TK tersebut dan juga beberapa guru membantu peneliti melakuakan observasi baik saat pretest maupun posttest. Keempat, adanya dukungan yang baik dari orang tua yang mana telah membolehkan anaknya untuk menjadi subjek penelitian. Kelima, adanya partisipasi aktif dari anak-anak usia 4-5 tahun di TK Tunas Harapan Emaus Liliba yang merupakan subjek dari penelitian. Hal ini ditunjukkan lewak sikap antusias anak-anak saat mengikuti proses belajarmengajar yang berlangsung. Keenam, penyampaian cerita menggunakan bahasa sederhana yang mudah dipahami oleh anak dan ekspresi wajah yang sesuai dengan emosi dalam cerita baik senang maupun sedih.

Di samping pembahasan mengenai faktor pendukung keberhasilan dari penelitian ini, terdapat beberapa hal yang merupakan keterbatasan dari penelitian ini, yakni: pertama, tidak melakukan diskusi dan evaluasi kepada oang tua mengenai sikap dan perilaku anak yang berkaitan dengan kemandirian yang ditunjukkan saat berada di rumah. Kedua,tidak memberikan informasi kepada para orang tua tentang bagaimana meningkatkan kemandirian anak terkait sikap dan perilaku saat berada di rumah.

\section{SIMPULAN}

Penerapan metode bercerita dengan media bergambar efektif secara signifikan meningkatkan kemandirian anak usia 4-5 tahun di TK Tunas Harapan Emaus Liliba, hal ini ditunjukkan melalui perbandingan hasil pretest (tes awal) dan posttest (tes akhir). Skor siswa kelompok A TK Tunas Harapan Emaus Liliba saat pretest berada pada taraf sedang dimana jumlah anak yang memperoleh skor 11-20 adalah 10 anak (frekuensi kumulatif) atau $90.90 \%$ (rekuensi relatif) dari 11 jumlah anak yang menjadi subjek penelitian, dan terdapat 1 anak (frekuensi kumulatif) atau $09.10 \%$ (frekuensi relatif) yang memperoleh skor bertaraf baik dengan skor 21. Skor siswa kelompok A TK Tunas Harapan Emaus Liliba saat posttest pada umumnya berada pada taraf baik, dimana terdapat 10 anak (frekuensi kumulatif) atau $90.90 \%$ (frekuensi relatif) yang memperoleh skor 21-30 dan hanya terdapat 1 anak (frekuensi kumulatif) atau $09.10 \%$ (frekuensi relatif) yang memperoleh skor bertaraf sedang dengan rentang skor 1120. Jadi jumlah keseluruhan subjek penelitian adalah 11 anak.

Efektifitas bercerita dengan media bergambar juga ditunjukkan dari nilai hasil pengolahan data yang menggunakan uji statistik Wilcoxon, yakni nilai Thitung bernilai 0,003. Karena nilai 0,003 lebih kecil dari nilai Ttabel yakni 0,05, maka dapat disimpulkan bahwa "Ha diterima". Artinya ada perbedaan peningkatan kemandirian skor posttest dari skor pretest, sehingga dapat disimpulkan pula bahwa terdapat peningkatan kemandirian anak dalam penerapa cerita bergambar terhadap anak usia 4-5 tahun di TK Tunas Harapan Emaus Liliba.

\section{SARAN}

Saran yang dapat diberikan adalah (1) cerita perlu diterapkan kepada anak TK baik di sekolah maupun saat berada di rumah karena sangat efektif untuk memberikan pengetahuan yang baru dan melatih daya ingat serta membangkitkan imajinasi anak berkaitan dengan sesuatu yang diceritakan, (2) cerita lokal perlu di kembangkan di TK sebagai 
Volume 6, Nomor 1, April 2019, hal 35 - 42

media untuk mengajarkan anak tentang nilainilai moral yang berlaku dalam masyarakat, agar terbentuk sikap dan perilaku yang baik sejak dini.

\section{DAFTAR PUSTAKA}

Arikunto, S. (2010). Prosedur Penelitian. suatu pendekaan penelitian. Edisi Revisi. Jakarta: rineka Cipta.

Arsyad. (2002). "Karakteristik Media Pembelajaran". Jakarta: PT. raja Garindo Persada.

Bachir, B. S. (2005). Pengembangan Kegiatan Bercerita di Taman Kanak-kanak, Teknik dan Prosedurnya. Jakarta: Depdiknas.

Hasan, A. (2002). Kamus Besar Bahasa Indonesia. Jakata: Balai Pustaka.

Itadz. (2008). Menyusun dan Menyajikan Cerita Untuk Anak Usia Dini. Yogyakarta: Tiara Wacana.

Kennedy, M. (2004). Melatih Anak Agar Mandiri. Jakarta: Erlangga.

Moeslichatoen. (2004). Metode Pengajaran di Taman Kanak - Kanak. Jakarta: Depdikbud.

Sudjana. (2002). Metode Statistik Edisi Ke-6. Bandung: Tarsito

Sugiyono. (2008). Metode penelitian kuantitati kualitatif dan $R \& D$. Bandung: Alfabeta.

Sugiyono. (2011). Metode Penelitian Kuantitatif Kualitatif dan $R \& D$. Bandung: Alfabeta.

Sugiyono. (2012). Memahami Penelitian Kualitatif. Bandung: Alfabeta.

Sumahamijaya. (2003). Pendidikan Karakteristik Mandiri dan Kewiraswataan, Bandung: Angkasa.

Susanto, A. (2012). Perkembangan Anak Usia Dini. Jakarta: Kencana
Suyanto, S. 2005. Konsep Dasar Anak Usia Dini. Jakarta: Departemen Pendidikan Nasional.

Tarigan, H. G. (1981). Berbicara Sebagai Suatu Keterampilan Berbahasa. Bandung: Angkasa.

Yamin, M. (2010). Kiat Membelajarkan Siswa. Jakarta: Gaung Persada Press. 